\title{
Research on Teaching Strategy of Art Literacy
}

\author{
Shuhan Chen, Haorong Yu \\ School of Fine Arts, Zhejiang Normal University, Jinhua, China \\ Email: 1272428472@qq.com
}

How to cite this paper: Chen, S.H. and $\mathrm{Yu}$, H.R. (2021) Research on Teaching Strategy of Art Literacy. Open Access Library Journal, 8: e8075.

https://doi.org/10.4236/oalib.1108075

Received: October 13, 2021

Accepted: November 13, 2021

Published: November 16, 2021

Copyright ( 2021 by author(s) and Open Access Library Inc.

This work is licensed under the Creative Commons Attribution International License (CC BY 4.0).

http://creativecommons.org/licenses/by/4.0/

\section{(c) (i) Open Access}

\begin{abstract}
As an important part of strengthening students' comprehensive literacy education in university education, art education can guide students not only to master the basic technical skills of art, but also to pay attention to the cultivation of aesthetic concept and art innovation concept, and further promote the combination of students' aesthetic quality education and art knowledge education. Art teachers need to fully combine the actual needs of students for art education content, speed up the adjustment of traditional teaching concepts, separate the explanation of theoretical knowledge, and with pictures, combined with simulated things, give play to students' active participation enthusiasm, effective practice and participate in the identification of theoretical knowledge. Teachers should be targeted in the whole process and teach students according to their aptitude. According to the theoretical knowledge system mastered by students, the theoretical knowledge system is divided into three parts, namely, basic theoretical knowledge, intermediate theoretical knowledge and advanced theoretical knowledge. Taking the practice of art literacy education as an example, this paper expounds the feasible measures to improve students' comprehensive literacy under the requirements of the new curriculum reform.
\end{abstract}

\section{Subject Areas}

Art, Teaching and Learning Technologies

\section{Keywords}

Art, Literacy Teaching, Operational Research

\section{Introduction}

Under the background of perfection and innovation in the field of education, the 
education department puts forward new curriculum reform requirements, requires art education to attach great importance to the cultivation of core quality, urges the school to accelerate the pace of cultivating comprehensive quality talents, and enables college students to improve the aesthetic and appreciation level in the field of art on the basis of actually mastering the professional knowledge of art, Further realize the integration and penetration of core literacy in art education courses, so as to promote the practical cultivation of students' art aesthetics and comprehensive quality. At present, as an important part of the cultivation of students' comprehensive quality, art education in the stage of university education plays a key role that can not be ignored in the whole education stage. The educational task of the school requires art teachers to constantly innovate teaching concepts in the practice of Art Literacy Teaching and actively introduce ideological and political education into art classroom teaching, in order to realize the aesthetic quality in art teaching classroom and promote the formation of students' core literacy.

\section{The Importance of Art Literacy Teaching Reform under the Requirements of the New Curriculum Reform}

\subsection{Practical Operation Instruction}

Design practice teaching is based on different situations of students in the process of experiment, full contact with each link, by obtaining tasks, looking for key painting steps, the teacher's theoretical guidance, so that students in the self-created environment, find problems, solve problems. At the same time, the school organized various professional interest groups to form a stepped teaching model. Give full play to the role of the group, in the discussion, to create understanding, promote the students practical teaching preliminary stage can also learn new knowledge [1]. Schools for students' comprehensive ability development wider interest group, the window will open out the teacher's personal resources, to the brand-new experience sharing, create and provide more independent practice platform for students, the teacher can also have a high-level students one-on-one guidance to the basic theory, form teacher DaiTu system, fully mobilize students' learning enthusiasm, In short, it is to learn deeply in the process, enrich practical experience in the theoretical knowledge system, and finally give full play to the teacher's subjective initiative for undifferentiated guidance. In this way, students can be promoted from theoretical knowledge to practical operation teaching, which is the integration of theory and practice, but also the technical creation of thinking, foreshadowing theoretical knowledge and strengthening professional guidance.

\subsection{Advanced Experience Sharing}

Led by the school, to carry out professional art competition, art technology competition and other activities, so that students fully participate in, and then 
achieve the role of checking and filling gaps, in the process of activities, can be divided into three links, respectively is theoretical knowledge questions and answers, practical operation technology competition, award-winning experience sharing. After three aspects are carried out, the system, integrity and operability of practical courses should be maintained, and students' professional skills should be strengthened by activities. Comments by high-level art talent also can invite famous art draw experience sharing in all directions, a line of the fine arts teacher authority to further promote students to learn art, can quickly enter the state, can also according to different students' problems in a reasonable guide experience, from professional theory share to professional knowledge training to the professional field test, training in all directions.

\subsection{Stimulate College Students' Art Creativity and Thinking Ability}

From the current situation of Art Literacy Education, college students have unlimited potential for art quality training. The practice of Art Literacy Education in teaching content can fully stimulate students' actual thinking and creative potential; Teachers speed up the development of Art Literacy Education in classroom practice, pay attention to observing students' actual literacy needs, encourage students to invest in art perception in skill practice, and trigger college students' Thinking on thinking judgment and core literacy. The most important thing is to provide good learning space for students' Art Literacy Education; As an educational platform for students to cultivate talents and show themselves, the school can help students provide opportunities for cultivating all-round talents of morality, intelligence, physique, art and labor, increase students' self-confidence, stimulate new thinking through art creation, and promote students to become all-round talents with continuous creativity and high intelligence.

\subsection{Create a Good Atmosphere for Art Literacy Education Classroom}

College students are particularly important in the cultivation of art aesthetics and comprehensive quality, which has a direct impact on their later learning and life behavior. Quality education is also the construction of sound campus culture, which can not be ignored in the construction of spiritual civilization system in Colleges and Universities under the new curriculum reform, Actively carrying out art literacy education can greatly expand students' analytical ability and art aesthetic ability, transmit art information to the brain through visual perception, and further form good skill learning; on the other hand, it also helps to create a good atmosphere for Art Literacy Education. Art education can effectively cultivate personal temperament, actively adjust students' negative and backward mood, prevent unhealthy physical and mental phenomena, further guide the classroom atmosphere of Art Literacy Education towards high quality, and carry out all-round positive influence on students' core literacy. 


\section{Innovative Strategies of Art Literacy Teaching Based on the New Curriculum Reform}

\subsection{Change the Teaching Concept and Create a Good Art Learning Space}

Under the requirements of the new curriculum reform, university education needs to strengthen its own reform and innovative thinking, and pay high attention to quality education on this basis. The most fundamental purpose of quality education is to ensure students' physical and mental health. In addition, as an important part of quality education, art literacy teaching can stimulate students' own creativity by improving students' art aesthetic ability; In addition, in the art education practice activities carried out by teachers, teachers also need to change the form of art education activities, fully combine the contents of students' interest, carry out corresponding art activities, and promote students to raise interest and actively participate in them. In the relaxed and pleasant learning space, it can also deepen the art communication between students and fundamentally promote the improvement of students' core literacy; And further achieve the development effect of art literacy teaching; In terms of teaching concept transformation and mode innovation, we should actively comply with the diversified needs of art classroom quality teaching under the new curriculum reform, combined with the actual situation of students' art literacy learning, so as to ensure that students have a strong interest in art learning space. Whether in the field of school education or family education space, we should reduce the prejudice against art quality teaching, strive to create a good and relaxed learning environment, and further stimulate students' enthusiasm for art learning [2].

\subsection{Strengthen the Integration of Art Education Resources and Quality Training}

Under the innovative environment of classroom teaching objectives of Art Literacy in the new era, art aesthetic education has gradually become an important content in quality training and teaching tasks in the current university stage. To a certain extent, it can promote schools and art teachers to pay attention to the transformation of their own traditional art teaching contents and models, and gradually break through the one-sided educational constraints of knowledge teaching, And pay attention to the integration and utilization of art education resources in classroom teaching, so as to ensure that college students are not limited by the traditional art education mode, so as to completely change the classroom practice mode of Art Literacy Education, and fundamentally promote and ensure the comprehensive and systematic utilization and development of art education resources in practical activities. Therefore, the school can actively formulate the system of art education to cultivate art emotion and pay attention to the education of core literacy. Art teachers need a beautiful mind to play their guiding role to ensure that students feel the educational value in the connotation of art and are imperceptibly influenced by art. Therefore, the integration be- 
tween art education resources and quality training is also to speed up the integration of art education aesthetics and people's emotional world proposed under the requirements of the new curriculum reform, which can lay a good foundation for students' art creation and quality improvement in the future. For example, the theme activities such as art theme class meeting and art emotion expression can greatly promote the utilization and expansion of art education resources in quality training.

\subsection{Strengthen the Development and Improvement of Art Literacy Teaching Practice}

Generally speaking, in the actual process of Art Literacy Education in the stage of university education, it is necessary to clarify the choice of education contents for students with different needs, and build art teaching objectives for different educated groups in combination with the characteristics of students' participation, To strengthen the development of art literacy teaching practice activities, school departments and teachers need to actively change the concept and activity form of Art Literacy Education, so as to ensure the full and effective development of art education activities. The most important thing is to pay attention to the dominant position of students in classroom practice activities and gradually cultivate students' premise foundation centered on their own quality needs; In the development of art education practice activities, accelerate the improvement of the effect of art education on students' core literacy. In the art class, lead students to taste and appreciate art melody, and master various art expression skills in time, so as to improve students' mastery of art skills and knowledge [3]. In addition, in the process of carrying out literacy teaching practice, art teachers should accumulate their own cultural heritage and create a spiritual background for students through the cultural communication and ideological exhibition of art. In order to improve students' art cultural literacy, we must put forward new requirements for teachers' art cultural heritage; In addition, the concept of Art Literacy pedagogy is also a systematic learning process. Teachers need to attach great importance to students' emotional development. In the process of practice, they can lead students into the art emotional world and enrich the emotional connotation. At the same time, they can also encourage students to create art and thinking to ensure that students' art literacy can be brought into full play. Therefore, under the background of art education practice activities, schools must actively expand the strength and effect of art education activities and further promote the effect of core literacy in practice activities.

\subsection{Promote the Perfection and Development of Art Literacy Education Mechanism}

In the current process of art literacy teaching reform, the university education stage does not pay attention to the construction, evaluation and assessment mechanism of art and quality education practice, which leads to the need for new reform ideas in the art literacy education mechanism. The backward art literacy 
education mechanism will lead to a certain impact on the art teaching content in the traditional teaching mode and the obstruction of the evaluation concept; In addition, in the operation of the evaluation mechanism of art education, the school pays attention to the cultivation of College Students' art education skills, but ignores the cultivation of students' personalized needs and Art Literacy to a great extent, resulting in that students can not be effectively influenced by aesthetic education and quality cultivation; This will also directly affect the serious backwardness of students' interested art thinking and aesthetic ability in the practical activities of art education, and then the formation of students' own art emotion, Art Literacy and values will be limited. Therefore, teachers need to fully combine the content and literacy needs of art classroom, and innovate teaching concepts to greatly stimulate students' learning enthusiasm, which is also an effective way to speed up the improvement of College Students' art learning literacy. In addition, the dissemination of art appreciation and art theory needs to closely focus on the diversified needs of educational reform. The innovation of Art Literacy Education is one of the specific manifestations of constantly adapting to the diversified needs of students under the conditions of the new era, As the key content of university teaching reform, art literacy education can promote students to fully realize the importance of core literacy and art skills, and actively participate in the educational practice of art literacy. In the practice of art literacy teaching, the integration of art teaching mode and content in the classroom helps to improve the disadvantages of traditional teaching methods, lay the foundation for the improvement and development of students' art literacy education mechanism, and further cultivate students' thinking ability and creative ability.

\section{Conclusion}

With the continuous improvement and reform of the system in the field of education, art education and quality training have gradually become the key links in the school teaching task; Art Literacy Education plays an important basic role in the whole stage of university education, which helps to improve students' modern comprehensive literacy and art aesthetic ability. At the same time, as a new educational method of cultivating talents, art teachers are required to strengthen the improvement of their own art quality under the new curriculum reform, play a guiding role in the classroom practice of students' Art Literacy more efficiently [4]. Besides, Kwai Tiktok and other short video information technology should be used to further innovate the goal of students' core literacy education in the new era. At the stage of college education, teachers need to pay more attention to students' art and quality needs, ensure students' dominant position in the practice of Art Literacy Education, and finally improve the promotion of all-round core literacy.

\section{Conflicts of Interest}

The authors declare no conflicts of interest. 


\section{References}

[1] Zhang, M.C. (2014) On the Current Situation and Improvement Countermeasures of Mathematics Teaching in Junior Middle School. Reading, Writing and Arithmetic (Education and Teaching Research), No. 25, 185.

[2] Niu, G. (2010) "People Oriented" Construction of Physical Education Incentive Mechanism. Journal of Zhenjiang College, No. 2, 108-110.

[3] Zuo, N. and Guo, J.L. (2017) On the Application of Artistic Expression in Documentary Creation. Contemporary Television, No. 8, 86-87.

[4] Jiang, Y.L. (2014) Research on the Strategy of Integrating Emotional Education into Art Teaching in Senior High School. Science Weekly, No. 2, 235. 